\title{
PENINGKATAN KEMAMPUAN IBU DALAM OPTIMALISASI PERKEMBANGAN BAYI MELALUI SENAM BAYI
}

\author{
KOEKOEH HARDJITO, ERNA RAHMA YANI, SUWOYO \\ Poltekkes Kemenkes Malang \\ Email : koekoeh_hardjito@poltekkes-malang.ac.id
}

\begin{abstract}
ABSTRAK
Orang tua selalu menginginkan bayinya mengalami perkembangan yang sesuai dengan usia. Salah satu cara untuk mencapai hal itu adalah memberikan stimulasi yang tepat. Pemberian senam bayi merupakan salah satu bentuk stimulasi yang dapat diberikan ibu pada bayinya. Banyak ibu yang tidak memiliki kemampuan dalam memberikan stimulasi. Pengabdian ini bertujuan membantu ibu untuk meningkatkan kemampuannya dalam memberikan senam bayi pada bayinya melalui kegiatan edukasi kepada ibu bayi. metode yang digunakan melalui pembelajaran klasikal, diskusi dan curah pendapat, demonstrasi, pemutaran video senam bayi dan observasi. Sasaran kegiatan adalah 15 ibu yang memiliki bayi direntang usia 6-12 bulan. Kegiatan dilaksanakan dalam 4 pertemuan, jarak antar pertemuan adalah 3 minggu. Evaluasi kegiatan dilakukan dengan mengamati perubahan pengetahuan ibu tentang senam bayi dari pre test dan post test, mengobservasi kemampuan ibu dalam memberikan senam bayi, serta mengamati kemampuan motorik bayi. Hasil kegiatan menunjukkan terjadi peningkatan pengetahuan ibu tentang senam bayi yang ditunjukkan perubahan rerata nilai pre test yaitu 44,44 menjadi 78,22 serta seluruh ibu mampu memberikan senam bayi sesuai usia bayinya dengan benar, seluruh bayi sudah memiliki kemampuan motorik sesuai usianya. Pengetahuan yang dimiliki ibu mendukung kemampuan ibu dalam memberikan stimulasi pada bayi melalui senam bayi dan akhirnya berdampak pada perkembangan bayi yang optimal.
\end{abstract}

Kata kunci: senam bayi, perkembangan motorik, stimulasi

\section{PENDAHULUAN}

Setiap orang tua menginginkan bayinya tumbuh sehat. Salah satu indicator kesehatan bayi adalah kemampuan bayi aktif bergerak sesuai dengan usianya. Untuk sampai tahap ini, orangtua rela melakukan berbagai cara yang dapat memacu perkembangan bayinya. Namun, masih sedikit orangtua yang mengetahui bahwa pertumbuhan sel-sel otak dipengaruhi oleh rangsangan dari lingkungannya. Pada masa awal tumbuh kembang anak,lingkungan yang sehat dan tepat menjadikan anaknya sehat. Tidak hanya fisiknya, melainkan otaknya juga. Sel-sel saraf akan mengalami perkembangan jika senantiasa diberi rangsangan atau stimulasi. Berbagai macam bentuk stimulasi yang dapat memacu perkembangan otak, seperti stimulasi dengan permainan, pemijatan, musik, dan senam bayi (Kusyairi, 2006)

Pada umumnya banyak faktor yang mempengaruhi pertumbuhan dan perkembangan bayi. Umumnya bayi bisa melakukan langkah pertamanya di umur 9-12 bulan. Kemudian, mereka mulai bisa berjalan di umur 14-15 bulan. Proses tumbuh kembang seharusnya diperhatikan dengan istimewa oleh para orang tua, terutama oleh ibu. Kemampuan orang tua untuk memberikan stimulasi merupakan hal yang mutlak diperlukan. Salah satu factor ekternal yang mempengaruhi tumbuh kembang bayi adalah stimulasi(Adriani \& Wirjatmadi, 2012)Perkembangan anak sangat terkait dengan posisi sosial ekonomi, pendidikan ibu dan stimulasi(Barros et al., 2010). Pemberian stimulasi terhadap bayi seringkali dilakukan oleh orang terdekat dari bayi. Senam bayi merupakan salah satu cara pemberian stimulasi. Kemampuan memberikan senam yang baik perlu dimiliki orang tua.

Senam bayi merupakan gerakan-gerakan yang dilakukan pada bayi, terutama persendian tulang dan otot. Bertujuan agar bayi siap menghadapi tahap perkembangan selanjutnya. Senam bayi juga bermanfaat sebagai stimulasi dalam permainan gerakan yang merangsang kemampuan gerak bayi serta tumbuh kembangnya.Idealnya, senam bayi baru bisa dilakukan ketika bayi berusia di atas 3 bulan, dimana kepala bayi sudah tidak lemah. Senam 


\section{EDUCATOR : Jurnal Inovasi Tenaga Pendidik dan Kependidikan Vol. 1 No. 1 September 2021, e-ISSN : 2807-8659 | p-ISSN : 2807-8829}

bayi terbagi menjadi tiga tahap yaitu, senam bayi tengkurap ke arah duduk, senam melatih bayi agar bisa duduk dan berdiri sendiri bagi bayi usia 6-9 bulan, dan tahap ketiga dimana senam bayi dipersiapkan agar bayi bisa merambat dan jalan mandiri(Hardjito et al., 2014).

Manfaat senam bayi antara lain melatih kekuatan dan ketahanan otot bayi agar lebih elastis dalam mempersiapkan perkembangan selanjutnya (Kusyairi, 2006). Selain itu juga dapat memperlancar peredaran darah pada bayi (Subakti \& Anggarani, 2011). Dalam penelitian(Hariani \& Arisandhi, 2015) yang berjudul Pengaruh senam bayi terhadap perkembangan bayi usia 3-12 bulan menunjukkan bahwa kelompok bayi yang diberikan senam bayi selama 4 minggu mengalami perkembangan yang sesuai dengan usianya dan lebih cepat berkembang dibandingkan kelompok yang tidak dilakukan senam.

Berdasarkan pemantauan di Posyandu RW 1 Kelurahan Pesantren Kota Kediri dijumpai 4 balita yang baru dapat berjalan pada rentang usia 17-18 bulan, dari 16 balita yang saat ini berusia $12-18$ bulan. Saat ini terdapat 15 bayi berusia 6-11 bulan di wilayah tersebut, Hasil pengamatan dan wawancara terhadap ibu bayi menunjukkan bahwa ibu telah mampu memenuhi kebutuhan nutrisi bagi bayinya dengan baik, keberanian ibu untuk menstimulasi gerakan motorik bayinya masih kurang serta pengetahuan ibu tentang stimulasi motorik anak dengan senam bayi masih belum baik. Mayoritas ibu bayi di wilayah posyandu ini berpendidikan SLTA dan dari aspek pekerjaan menunjukkan mayoritas ibu tidak bekerja. Keadaan ini memberikan kemudahan bagi ibu untuk memberikan stimulasi senam bayi bagi bayinya.

Dengan melihat latar belakang diatas, tim pengabdian kepada masyarakat ingin membantu ibu untuk meningkatkan kemampuannya dalam memberikan senam bayi pada bayinya melalui kegiatan edukasi kepada ibu bayi.

Kegiatan ini bertujuan agar Ibu bayi mampu memberikan stimulasi gerak motorik pada bayi melalui kegiatan senam bayi dengan benar. Manfaat yang diharapkan dari kegiatan ini adalah memberikan kesempatan kepada ibu untuk saling bertukar pengalaman dalam menstimulasi tumbuh kembang anak serta tumbuh kembang anak dapat berjalan sesuai usia.

\section{METODE PENELITIAN}

Kegiatan pengabdian ini dilakukan dengan metode pembelajaran klasikal, diskusi dan curah pendapat, demonstrasi, pemutaran video senam bayi dan observasi. Kegiatan dilaksanakan dalam empat pertemuan, jarak antar pertemuan adalah tiga minggu.

a. Pertemuan I, dilaksanakan pre tes bagi ibu dan penyuluhan senam bayi yang dihadiri oleh seluruh ibu dan bayi sebanyak 15 ibu beserta bayinya. Terdiri dari 9 bayi kelompok usia 6 - 9 bulan dan 6 bayi kelompok usia $10-12$ bulan. Kegiatan dilanjutkan dengan diskusi dan tanya jawab dan sekaligus pelaksanaan senam yang dipandu oleh tim pengabmas.. Pada saat itu diberikan peralatan yang dapat digunakan untuk senam dirumah berupa matras, bantal, kursi kecil, buku panduan senam. Buku panduan ini diberikan kepada ibu untuk dipelajari di rumah jika sewaktu-waktu mengalami kendala dalam memberikan senam bayi. Kegiatan pre tes bertujuan untuk mengetahui sejauh mana pemahaman ibu tentang senam bayi.

b. Pertemuan II, dilaksanakan monitoring pertama kemampuan ibu untuk melakukan stimulasi motorik senam. Pada saat itu oleh tim pengabmas diputarkan ulang materi senam bayi kepada seluruh peserta.

c. Pertemuan III, dilaksanakan monitoring kedua untuk melihat kemampuan ibu memberikan senam kepada bayinya.

d. Pertemuan IV, dilaksanakan post tes pada ibu serta evaluasi kemampuan motorik bayi. Pada pertemuan IV ini rentang usia bayi adalah $8-11$ bulan dan $12-14$ bulan.

Proses monitoring dilakukan dengan mengobservasi kemampuan ibu dalam memberikan senam bayi, proses ini dilakukan pada seluruh peserta.

Perubahan pemahaman ibu tentang senam bayi dianalisa secara deskriptif berdasarkan data pre tes dan post tes. 


\section{HASIL DAN PEMBAHASAN}

\section{Hasil}

Berikut hasil dari nilai pengetahuan ibu tentang senam bayi.

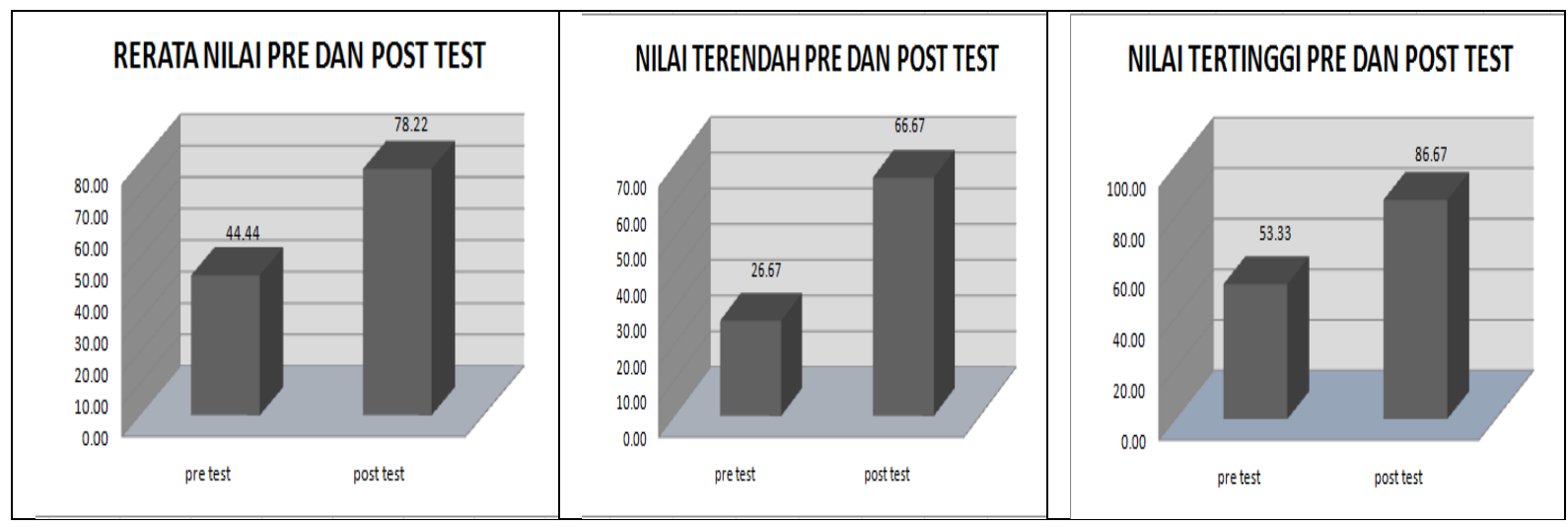

\section{Gambar 1. Nilai pengetahuan ibu tentang senam bayi antara pre dan post test}

Gambar 1 di atas menunjukkan terjadi peningkatan pengetahuan ibu tentang senam bayi. Pada rerata nilai pre test adalah 44,44 meningkat menjadi 78,22 saat post test. Nilai terendah 26,67 saat pre test menjadi 66,67 saat post test. Nilai tertinggi saat pre test 53,33 meningkat menjadi 86,67 saat post test.

Pada pertemuan II, hasilnya masih dijumpai beberapa orang ibu yang masih takut memberikan latihan senam pada bayinya. Beberapa gerakan yang sulit dilakukan oleh ibu adalah menyangga dada bayi dengan bantal dan kedua tangan bayi menumpu lurus di depan badan dalam posisi merangkak. Secara perlahan, angkat kedua tungkai lurus ke atas. Pertahankan posisi ini beberapa detik. Rangkaian kegiatan tersebut dirasakan agak sulit oleh ibu karena posisi anak bertumpu pada lengan. Beberapa bayi belum mampu melakukan gerakan ini.

Pada pertemuan III, seluruh ibu mampu memberikan senam pada bayinya. Pada gerakan bayi tengkurap, ibu berada di belakang bayi, menarik panggul bayi ke posisi merangkak merupakan rangkaian gerakan yang relatif mudah dilakukan bayi usia 8-9 bulan. Kegiatan pengabdian ini diikuti dengan baik oleh ibu dan bayi berikut ini gambar pelaksanaan senam bayi.

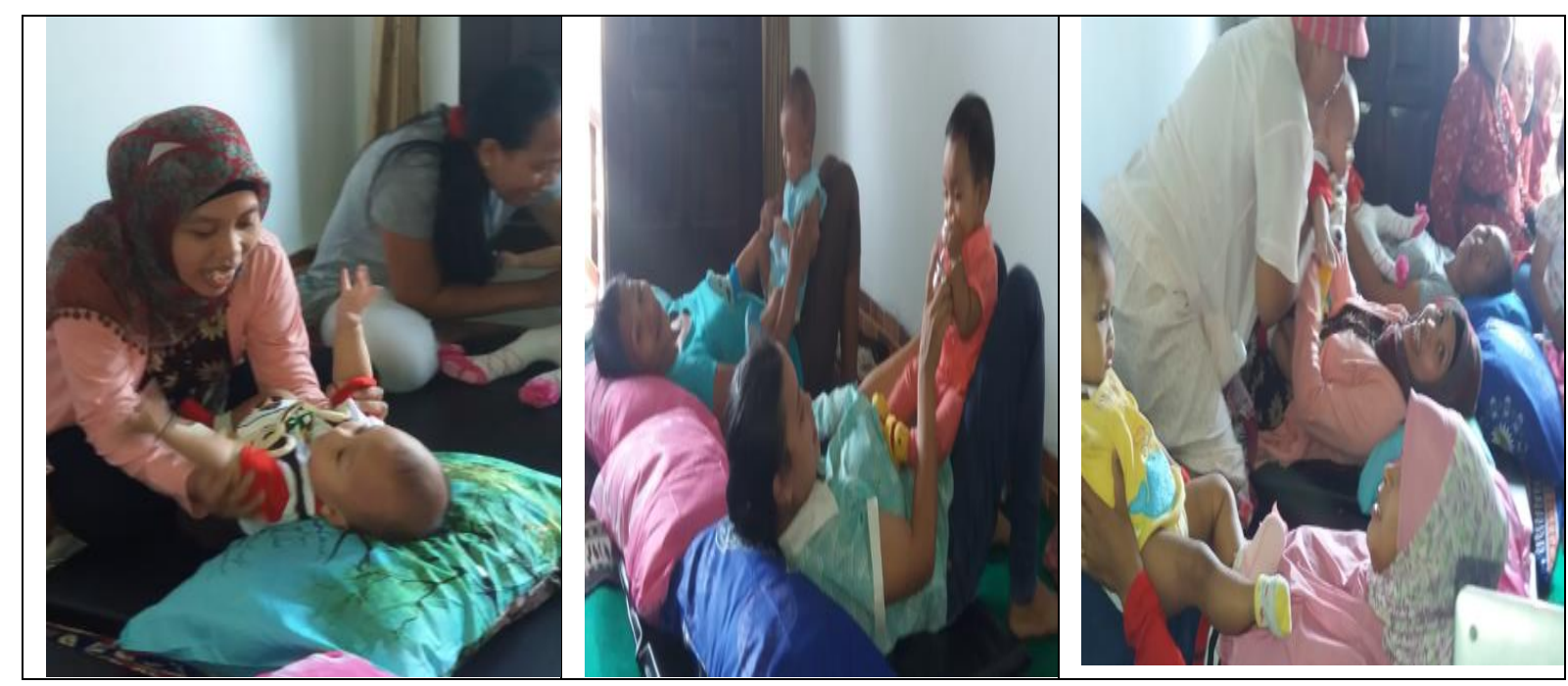

Gambar 2. Kegiatan senam bayi 


\section{EDUCATOR : Jurnal Inovasi Tenaga Pendidik dan Kependidikan Vol. 1 No. 1 September 2021, e-ISSN : 2807-8659 | p-ISSN : 2807-8829}

Gambar 2 menunjukkan ibu bayi telah mampu memberikan senam bayi pada bayinya. Tampak ibu sangat aktif dalam memberikan sentuhan, gerakan senam dengan lembut dan hubungan ibu dengan bayi terlihat erat. Pada pertemuan IV, hasilnya adalah seluruh bayi yang ada direntang usia 6 - 9 bulan sudah memiliki kemampuan motorik sesuai usianya yaitu duduk, merangkak . Kelompok bayi di rentang usia 10 - 12 bulan sudah mencapai kemampuan berdiri tanpa bantuan, berjalan dengan merambat, berjalan 2 hingga 3 langkah tanpa bantuan, dan bahkan ada 3 anak yang mampu berjalan 10 menit tanpa bantuan

\section{Pembahasan}

Pada awal kegiatan rerata nilai pengetahuan ibu tentang senam bayi adalah kurang, Hal ini dapat disebabkan karena kurangnya informasi tentang senam bayi yang didapatkan atau bahkan sama sekali belum pernah mendengar tentang senam bayi yang menyebabkan banyak dari responden tidak menerima. Hal ini bisa juga disebabkan responden pernah mendengarkan atau mendapat informasi tentang senam bayi tetapi ibu kurang memahami sehingga ibu juga tidak menerima tentang senam bayi. Menurut Azwar (2009) Kepercayaan datang dari apa yang telah kita lihat kemudian terbentuk suatu ide atau gagasan mengenai sifat atau karakteristik umum suatu objek. Tentu saja kepercayaan sebagai komponen kognitif tidak selalu akurat. Kadang-kadang kepercayaan itu terbentuk justru dikarenakan kurang atau tiadanya informasi yang benar mengenai suatu objek yang dihadapi.

Pada saat penyuluhan dilaksanakan respon ibu sangat bagus, hal ini ditunjukkan dengan berbagai pertanyaan yang diajukan serta permintaan dari ibu untuk mengulang beberapa gerakan yang dirasakan cukup sulit untuk dilaksnakan. Namun demikian pada hasil masih terdapat beberapa responden yang mengalami kesulitan dalam melaksanakan senam bayi. Kesulitan tidak hanya pada teknis pelaksanaan gerakannya, tetapi juga menjaga kesiapan bayi dalam melaksanakan senam merupakan hal yang tidak mudah dilakukan. Kegiatan senam bayi ini memerlukan kerjasama yang sangat baik antara ibu dan bayi. Ibu harus mampu mengenali kondisi kesiapan diri dan bayi dalam melaksanakan senam bayi.

Beberapa hal yang terjadi dalam pemantauan tiap gerakan senam menunjukkan bahwa terdapat gerakan-gerakan yang cukup mudah dilakukan dan gerakan yang sulit pada tiap kelompok usia. Gerakan mudah pada usia 7-9 bulan antara lain saat ibu menarik kedua tangan bayi dan membawa bayi ke posisi duduk. Gerakan semacam ini mudah dipahami oleh ibu, kekawatiran terhadap kesalahan gerakan juga rendah sehingga ibu mudah melaksanakannya. Contoh gerakan yang sulit adalah memiringkan bayi lalu menarik kaki ke depan agar bayi mencoba berdiri pada kelompok bayi usia 10-12 bulan. Gerakan ini memerlukan kesabaran, memperhatikan kemauan bayi, situasi dalam melaksanakan gerakan, tidak terburu-buru serta kerjasama yang baik antara ibu dan bayi. Kebersamaan ibu dengan bayi ketika melakukan senam bayi bermakna sangat dalam. Saat-saat nyaman ketika melakukan senam bayi bersama ibu, tidak hanya membuat tubuh bayi sehat dan bugar, tetapi bayi pun tumbuh menjadi anak yang bahagia dan percaya diri.

Beberapa ibu yang pada pertemuan II masih menunjukkan rasa takut, suatu hal yang wajar bila pada awalnya seorang ibu memiliki rasa takut dalam memberikan senam pada bayinya, umumnya mereka beranggapan bahwa bayi belum memerlukan stimulasi semacam itu. Hal ini didukung oleh anggapan bahwa tulang bayi belum kuat untuk dilakukan senam. Kata senam bayi dapat diartikan seperti halnya senam-senam pada umumnya oleh sebagian ibu. Maka disinilah pentingnya tim pengabdi menyampaikan ulang materi senam ini pada pertemuan kedua. Keadaan tersebut sejalan dengan penelitian yang dilakukan oleh (Munawaroh, 2015) tentang keterkaitan antara pengetahuan ibu dengan pemberian stimulasi pada bayi, yang hasilnya adalah dijumpai hubungan antara tingkat pengetahuan ibu tentang tumbuh kembang bayi dengan stimulasi tumbuh kembang pada anak usia 6-9 bulan.

Rasa takut yang dialami ibu di awal kegiatan sejalan dengan penelitian (Hardjito et al., 2014) yang berjudul pengaruh penyuluhan tentang senam bayi terhadap kemampuan ibu dalam melaksanakan senam bayi dimana terdapat suatu fakta bahwa rendahnya prosentase ibu yang 


\section{EDUCATOR : Jurnal Inovasi Tenaga Pendidik dan Kependidikan Vol. 1 No. 1 September 2021, e-ISSN : 2807-8659 | p-ISSN : 2807-8829}

mampu melaksanakan senam bayi dapat disebabkan karena budaya yang berkembang disana, bahwa jika bayi masih kecil tidak boleh digerakkan berlebihan karena takut salah urat walaupun sebenarnya gerakan senam bayi sudah disesuaikan dengan usia perkembangan bayi tersebut. Hal tersebut karena informasi yang didapatkan tidak lengkap dan akurat. Kondisi tersebut memiliki makna bahwa budaya berperan dalam pembentukan sikap seseorang, hal ini sesuai dengan pendapat(Azwar, 2009) bahwa kebudayaan dimana kita hidup dan dibesarkan mempunyai pengaruh yang besar terhadap pembentukan sikap kita. Tanpa kita sadari, kebudayaan telah menanamkan garis pengarah sikap kita terhadap berbagai masalah. Kebudayaan telah mewarnai sikap anggota masyarakatnya, karena kebudayaan pulalah yang memberi corak pengalaman individu-individu yang menjadi anggota kelompok masyarakat asuhannya. Hanya kepribadian individu yang yang telah mapan dan kuatlah yang dapat memudarkan dominasi kebudayaan dalam pembentukan preilaku individual.

Pada pertemuan IV diperoleh nilai pengetahuan yang meningkat dari ibu bayi. Pemberian edukasi yang disertai praktik langsung dapat mempermudah ibu menerima pesan yang disampaikan. Sejalan dengan pendapat Maslow(Fahyuni \& Istikomah, 2016) bahwa motif belajar ditentukan oleh berbagai kebutuhan individu, yaitu kebutuhan fisik, rasa aman, bebas dari kekawatiran, cinta dan kasih saying. Hal ini yang terjadi pada ibu bayi, bahwa kebutuhan yang dirasakan tidak hanya untuk memenuhi dirinya sendiri tetapi juga bagi bayinya. Kebutuhan agar bayinya dapat tumbuh berkembang dengan baik menjadikan mereka semangat untuk belajar, berlatih memberikan senam pada bayinya. Selain motivasi belajar tersebut hal yang menjadikan ibu semangat meningkatkan pengetahuan adalah bahwa kegiatan senam ini menjadikan kedekatan antara ibu dan bayi semakin erat (Purwanti, 2013)

Gerakan-gerakan senam yang diajarkan pada ibu merupakan gerakan yang aman sesuai usia bayi, Pemahaman yang baik tentang senam bayi menjadikan responden memiliki kemampuan dalam melaksanakan senam bayi. Metode yang digunakan pada penyuluhan ini adalah demonstrasi, serta penayangan video senam bayi jadi ibu bisa melihat secara langsung gerakan-gerakan dari senam bayi. Ibu juga bisa menanyakan gerakan mana yang tidak dimengerti dan mengulanginya bersama-sama. Hal ini dapat menanamkan dengan baik tentang senam bayi dan ibu juga bisa mengerti tiap gerakan yang diajarkan. Di dalam bukunya (Simamora, 2009) menjelaskan bahwa kelebihan metode demonstrasi adalah membantu responden memahami dengan jelas jalannya atau cara melakukan sesuatu, memudahkan berbagai jenis penjelasan, dan kesalahan yang terjadi dari hasil ceramah dpat diperbaiki melalui pengamatan dan contoh konkret dengan menghadirkan objek sebenarnya.

Pada akhir pertemuan didapatkan data bahwa kelompok bayi sudah memiliki kemampuan motorik sesuai usianya. Hal ini sejalan dengan penelitian (Purwanti, 2013) yang menunjukkan bahwa bayi yang mendapatkan stimulasi dengan senam bayi mayoritas perkembangan yang normal. Kegiatan senam bayi memerlukan kesiapan tidak hanya bagi bayi tetapi ibu juga harus siap, jika sewaktu-waktu ada kebosanan dari bayi maka sebaiknya segera dihentikan atau dialihkan gerakan atau kegiatannya dengan sentuhan lembut ibu. Selain itu ibu dituntut memiliki ketelatenan yang tinggi, dimana sikap ini pada umumnya sudah melekat pada diri seorang ibu.

\section{KESIMPULAN}

Dari pengabdian ini dapat disimpulkan terdapat peningkatan pengetahuan ibu tentang senam bayi, ibu bayi telah mampu memberikan stimulasi gerak motorik pada bayi melalui kegiatan senam bayi dengan benar. Perkembangan gerak motorik bayi dalam kondisi normal sesuai usia. Hal ini menunjukkan bahwa pengetahuan yang dimiliki ibu mendukung kemampuan ibu dalam memberikan stimulasi pada bayi melalui senam bayi dan akhirnya berdampak pada perkembangan bayi yang optimal. 


\section{DAFTAR PUSTAKA}

Adriani, M., \& Wirjatmadi, B. (2012). Peranan gizi dalam siklus kehidupan. Jakarta: Kencana Prenada Media Group.

Azwar, S. (2009). Sikap Manusia: Teori dan Pengukurannya (edisi 2). Jogjakarta: Pustaka Pelajar.

Barros, A. J., Matijasevich, A., Santos, I. S., \& Halpern, R. (2010). Child development in a birth cohort: Effect of child stimulation is stronger in less educated mothers. International Journal of Epidemiology, 39(1), 285-294. https://doi.org/10.1093/ije/dyp272

Fahyuni, E. F., \& Istikomah. (2016). Psikologi Belajar \& Mengajar. Sidoarjo: Nizamia Learning Center.

Hardjito, K., Yani, E. R., \& Rahayu, D. E. (2014). Pengaruh Penyuluhan Tentang Senam Bayi Terhadap Kemampuan Ibu Dalam Melaksanakan Senam Bayi. Poltekkes Kemenkes Malang. http://kin.perpusnas.go.id/DisplayData.aspx?pId=3571\&pRegionCode=JIPKMAL\&p ClientId $=111$

Hariani, W. F., \& Arisandhi, D. (2015). Pengaruh senam bayi terhadap perkembangan bayi usia 3-12 bulan di Perkebunan Bayu Kidul Kecamatan Songgon Kabupaten Banyuwangi. Healty Jurnal, 4(1), 9. https://www.ojsstikesbanyuwangi.com/index.php/healthy/article/view/46

Kusyairi, I. C. H. (2006). Panduan senam bayi: Biarkan ia berkembang menjadi pribadi yang aktif, sehat dan percaya diri. Puspa Swara.

Munawaroh, A. (2015). Hubungan tingkat pengetahuan ibu tentang perkembangan bayi dengan pemberian stimulasi perkembangan bayi usia 6 - 9 bulan di Wilayah Kerja Puskesmas Dharmarini Kabupaten Temanggung tahun 2014. Jurnal Kebidanan, 4(8), 11. https://ejournal.poltekkes-smg.ac.id/ojs/index.php/jurkeb/article/view/397/334

Purwanti, S. (2013). Efektifitas Pelaksanaan Senam Bayi Terhadap Peningkatan Perkembangan Bayi. INVOLUSI Jurnal Ilmu Kebidanan, 3(6). http://jurnal.stikesmukla.ac.id/index.php/involusi/article/view/154

Simamora, R. H. (2009). Buku Ajar Pendidikan Dalam Keperawatan. Jakarta: EGC.

Subakti, Y., \& Anggarani, D. R. (2011). Panduan pintar pengasuhan bayi minggu per minggu agar sehat, cerdas, \& shaleh. Jakarta: Qultum Media. 